\title{
Task-Based Language Assessment: Implications for the Language Classroom ${ }^{1}$
}

La Evaluación de Lenguas Basada en Tareas: Implicaciones para el Aula de Lenguas Extranjeras

\section{Frank Giraldo ${ }^{2 *}$}

Universidad de Caldas, Colombia

\footnotetext{
${ }^{1}$ Received: November 12th 2019/ Accepted: August 8th 2020

2 frank.giraldo@ucaldas.edu.co
} 


\section{Abstract}

With a communicative approach to language testing, performance assessment has taken on a prominent role in testing systems around the world. Specifically, Task-Based Assessment (TBA) is now being used to make inferences about people's language ability and what they can do with this construct under realistic communicative scenarios. This reflection paper discusses central issues in TBA, and in doing so, it shows that TBA can be observed through a classroomassessment lens, an idea I present as Instructional Task-Based Assessment (ITBA). The paper starts by reviewing the meaning of tasks, then discusses problems with TBA and finally offers a list of principles for teachers to explore TBA in classroom contexts. I also include limitations of the proposal and conclusions.

Key words: alternative assessment; language assessment; language testing; performance assessment; task-based assessment.

\section{Resumen}

Partiendo del enfoque comunicativo en evaluación de lenguas, la necesidad de evaluar la competencia comunicativa ha conllevado al diseño de pruebas estandarizadas alrededor del mundo. En especial, la evaluación de lenguas basada en tareas (TBA sus siglas en inglés) se usa como una manera de inferir qué es lo que pueden hacer las personas con su habilidad de lengua en encuentros reales comunicativos. Este artículo de reflexión examina temas claves en TBA, y mediante esta discusión, sugiere que TBA puede analizarse desde el salón de clases; esta es una propuesta que presento como Evaluación de Lenguas Basada en Tareas en Contextos Pedagógicos (ITBA sus siglas en inglés). El artículo comienza con una revisión del significado de tareas, luego analiza los problemas relacionados con TBA y, finalmente, ofrece una lista de principios para que los docentes de lenguas exploren TBA en sus contextos educativos. De igual manera, incluyo algunas limitaciones de la propuesta y conclusiones del artículo.

Palabras claves: evaluación de desempeño; evaluación de lenguas; evaluación de lenguas basada en tareas; evaluación formativa. 


\section{Resumo}

Partindo do enfoque comunicativo em avaliação de línguas, a necessidade de avaliar a competência comunicativa levou ao desenho de provas padronizadas ao redor do mundo. Em especial, a avaliação de línguas baseada em tarefas (TBA suas siglas em inglês) usada como uma forma de inferir as pessoas e o que pode fazer com a sua habilidade de língua em encontros reais comunicativos. Este artigo de reflexão examina temas chaves em TBA, e mediante esta discussão, sugere que TBA pode analisar-se desde as salas de aula; esta é uma proposta que apresento como Avaliação de Línguas Baseada em Tarefas em Contextos Pedagógicos (ITBA suas siglas em inglês). O artigo começa com uma revisão do significado de tarefas, logo analisa os problemas relacionados com TBA e, finalmente, oferece uma lista de princípios para que os docentes de línguas explorem TBA em seus contextos educativos. Da mesma forma, incluo algumas limitações da proposta e conclusões do artigo.

Palavras chaves: avaliação de desempenho; avaliação de línguas; avaliação de línguas baseada em tarefas; avaliação formativa. 


\section{Introduction}

he Communicative Language Teaching (CLT) movement that started in the 1960's brought with it a new perception of language learning. The field decided to look at language from a communication point of view and no longer as an accumulation of rules, (Richards \& Rodgers, 2001) through the goal of language learning: The development of communicative language ability (Bachman \& Palmer, 1996; Fulcher, 2010; Richards \& Rodgers, 2001). One way to operationalize the rather philosophical view of language in CLT was to think of tasks as a way to teach, learn, and assess language ability. Task-Based Assessment (henceforth TBA) uses tasks as core vehicles to activate and observe language being used to achieve real-life purposes and derive interpretations of what test takers or learners can do with their language ability (Bachman, 2002; Ellis, 2003; Norris, 2016). The literature in taskbased assessment has primarily been focused on testing, not on the implementation of tasks for language assessment in the classroom; for instance, Ellis (2003), in an entire chapter, dedicates only three pages to TBA in the classroom. Similarly, Wigglesworth and Frost (2017) dedicate one paragraph to classroom TBA, through which they state the usefulness of TBA as it can match teaching.

Given that there is scarce literature on TBA as it is implemented in the classroom context, in this reflection paper I look at task-based assessment from an instructional perspective; that is, TBA as teachers and learners engage in it. This view aligns with a call that scholars in TBA have recently made, namely the need to understand TBA in classroom contexts (Bygate, 2016; Norris, 2016). I start the paper with an overview of tasks in language instruction and move to a definition of TBA. Later, I review core issues in classroom TBA and discuss the notion of Instructional TBA (henceforth ITBA). I then close the paper with a list of principles for applying TBA in the classroom, followed by relevant limitations and conclusions.

\section{Literature Review}

Any discussion around TBA and task-based instruction should necessarily scrutinize the meaning of tasks. The literature in language teaching has defined tasks as a spectrum, from the communicative grammar activity, to the strong form of real-life activities that need language for accomplishment (Van den Branden, 2006). While the definitions are indeed many, the consensus is that learners use their language knowledge and skills to perform activities which need the use of language (e.g. opening a bank account). The purpose of tasks is not to have students show their explicit knowledge of, for example, grammar structures, but what they can do with them in a real-life communicative encounter. Thus, tasks are not to study language 
forms; they are focused on meaning-making through forms (Van den Branden, 2006; Willis \& Willis, 2007).

In fact, tasks have gained major attention in language education and have become the center of language programs and language testing. Consequently, in a strong form of task-based teaching, language syllabi are designed around tasks, whereas a weak form uses them as an add-on to language learning (Ellis, 2003; Willis \& Willis, 2007). As types of tasks, Willis and Willis (2007) include listing, ordering and sorting, matching, comparing, sharing personal experiences, projects and creative tasks, and problem-solving. There are, additionally, other types of tasks that are present in the literature, for example opinion-exchange (Pica, Kanagy, \& Falodun, 1993). Similarly, in a TBA framework, language testing uses tasks mainly to elicit and assess learners' language ability in action (Brindley, 1994; Norris, 2016). Large-scale tests such as the Test of English as a Foreign Language (TOEFL) (Chapelle, Enright \& Jamieson, 2007) use tasks to ascertain how test takers can cope with academic language demands in English-medium universities. Task-based tests such as the TOEFL, following a communicative approach, do not require test takers to show their linguistic knowledge but rather what they can do with it in academic environments.

Along these lines, task-based language assessment can be classified as a sort of performance assessment (Brindley, 2013; Brown, 2004), for TBA differs from traditional language testing in which a structural view of language was paramount. Rather, TBA engages test takers in replicating real-life uses of language through the use of their linguistic and even non-linguistic resources (Brindley, 1994). Additionally, Ellis (2003) claims that TBA involves real world behavior (what people accomplish with language) and processing (how people accomplish it). As in task-based teaching, TBA is meaning-focused and goal-oriented. This orientation feeds back on the meaning of performance: Test takers do something through and with language. As Norris (2016) explains, task completion through performance is essential in TBA, because it is task performance what matters to make decisions about learners.

However, while task completion is indeed important in TBA, the task has to provide evidence of learners' language ability (Bachman, 2002; Ellis, 2003). Bachman (2002) argues that TBA is problematic in the sense that learners may do well on a test task but this cannot be replicable in other contexts, essentially because of the limitations of the task itself. Therefore, what is needed is a full picture of the learner's language ability, i.e. the construct under consideration. Bachman argues that in order to make valid decisions based on TBA data, a counterbalanced approach is needed, where taskcentered and construct-centered designs are combined. 


\section{Issues in Task-Based Assessment}

As presented above, the information tasks give to testers may be problematic as learners could cope with tasks by implementing non-linguistic strategies, namely non-verbal communication. While the discussion of a task-centered and/or construct centered design to TBA is ongoing (Bachman, 2002; Ellis, 2003), the final decisions in testing should be based on language ability, as other non-linguistic factors are still not theoretically part of language ability models in language testing (see Fulcher, 2010).

Other common issues in TBA are indeed interrelated and feed back on the validity of decisions made from test scores. Among issues receiving attention are TBA's authenticity, representativeness, generalizability, and inseparability (Ellis, 2003; Skehan, 1984). In terms of authenticity, authors agree that merely replicating an activity from the real world does not make a TBA informative (Bachman, 2002; Chalhoub-Deville, 2001; Norris, 2016). Authenticity needs to be embedded in a test from a situational and discourse point of view (Chalhoub-Deville, 2001), involve authentic participants (Bachman, 2002) and be as realistic as possible, although this is not fully achievable as tests are artificial by nature (Bachman, 2002; Brindley, 2013).

What is more, authors agree that it is challenging to either generalize from a task performance to a wider target language use in real scenarios, or collect a good enough sample of data to ascertain confidently what a person can really do with language (Bachman, 2002; Ellis, 2003; Kim, 2004; Norris, 2016). Generalizability and representativeness are specifically problematic when arguing for the validity of general proficiency (construct-based) tests. For example, if a test taker performs an oral task well (negotiate a bank transaction), it may not be argued that $\mathrm{s} /$ he can negotiate in other non-testing contexts or that the test/task includes enough contexts and language to support the same conclusion.

A task-centered approach is, however, key in occupational language tests (Kim, 2004). A task for traffic controllers is a classic example of task-centered design. The TBA has to provide evidence that the candidate can (or cannot!) help a pilot land a plane safely, and he/she should be able to mobilize language to accomplish exactly such task. As authors argue, successful task completion in this approach is paramount (Kim, 2004; Norris, 2016).

A major area of concern in TBA is its reliability (Brindley, 2013; Ellis, 2003). One of the causes of unreliability is the inconsistency of scores given by human raters. Additionally, test-taker characteristics (e.g. anxiety) and faulty test administration may lead to fluctuations in scores. Together, all these factors make test scores unreliable, and therefore invalid. As a way to ameliorate TBA reliability in classroom contexts, Ellis (2003) suggests that the test be lengthened, scored by at least two raters, and raters be trained in assessing performance. 
Another challenge in TBA is what Ellis (2003) calls inseparability. This refers to candidates calling upon their world knowledge in a TBA situation. As the author argues, if a candidate is more familiar than others with the content (or topic) of a TBA, then he/she is at an advantage; therefore, low scores from test takers who have no background in the topic, and who do poorly because of this fact, may not say much about these people's language ability: They got low scores due to something unrelated to this construct. However, as Ellis explains, performance in a language test requires content knowledge, rendering language and content inseparable. As a recommendation, authors suggest that assessment rubrics include criteria for language and content (Douglas, 2001; McNamara, 1996). On this same line, Brindley (1994; 2013) asserts that scoring criteria in TBA, whether in testing or classroom scenarios, must be comprehensive and transparent; these criteria must include the language aspects to be examined, as well as the task-centered factors that can influence performance (e.g. level of participation in a roleplay, in terms of time).

Creating criteria for language assessment may be challenging for the construct validity of TBA (Brindley, 2013). First, expert-based design of criteria may misrepresent the central construct (i.e. language ability) and not include all relevant information for all the skills necesarry to do the task under consideration; second, available theoretical descriptions of language ability are difficult to operationalize and lack other dimensions (e.g. relation between test taker and interlocutor); and third, available criteria such as those found in the Common European Framework (Council of Europe, 2001) are not sufficiently validated (Fulcher, 2010).

All in all, while problems in TBA may cast doubt upon decisions made from this approach, authors still support the use of tasks for language assessment, provided that

- $\quad$ tasks are comprehensively described and aligned with the language constructs they elicit information about (Bachman, 2002; Brindley, 2013; ChalhoubDeville, 2001);

- tasks engage students in using realistic language for authentic activities (Ellis, 2003; Long, 2015; Norris, 2016);

- there is a balance between construct-centered and task-centered design (Bachman, 2002; Ellis, 2003; Mislevy, Steinberg, \& Almond, 2002);

- assessment criteria are comprehensive enough to validly assess task performance of linguistic and non-linguistic issues (Brindley, 1994; ChalhoubDeville, 2001; Kim, 2004).

- last but not least, the language constructs that tasks are supposed to activate must be substantively described (Bachman, 2002; Brindley, 1994; 2013). 


\section{Task-Based Assessment in Language Education}

Scholars in the area of task-based assessment agree on the features of this type of assessment in instructional contexts. For example, Norris $(2009 ; 2016)$ and Long (2015) state that task-based assessments can be used for summative and formative purposes. However, since the idea is to help students develop their language ability for communicative tasks, formative uses are prime for task-based assessment, an idea Nunan (2004) strongly supports. Formative assessment, as discussions and research have shown, happens in the form of peer-, self-, and portfolio assessment (Leedham, 2005; Norris, 2016; Nunan, 2004; Weaver, 2012). Feedback from these sources is meant to improve performance at the level of language use (construct-centered) as well as the task itself (task-centered).

In terms of the actual use of task-based assessment in class, this approach tends to have clear stages. In his study, Weaver (2012) presents four interrelated stages of taskbased assessment: task selection; task definition and assessment criteria; assessment implementation and task performance; and feedback. In the study, the author had students select a task (business oral presentation), gave students the criteria to be used, and engaged them in peer assessment. This approach helped the group to perform their oral presentations successfully.

In a similar vein, Leedham's (2005) study implemented a task-based assessment to help students improve their performance in a large-scale test, specifically in a task for discussing the suitability of a room for an event. The stages included an initial performance of the task, then students listening to native speakers doing the task, and finally students repeating the task. In this sequence, students identified language used by speakers and incorporated this learning in their second performance of the task.

Other research studies looking at TBA in educational contexts agree on a set of core features. The study by Chuanren (2006) aligned tests, curriculum, and teaching with the hopes to consolidate a coherent focus of instruction, where tasks played a predominant role. The study by Byrnes (2002) looked at task-based assessment as a transition from a form-focused to a meaning-focused approach to language learning. In both studies, it is clear that TBA in the classroom has an impact on curricula, teaching, and the teachers themselves. Based on these two studies, it can be confirmed that TBA may bring about positive change to language programs, a generally held notion among TBA scholars (Brindley, 1994; 2013; Norris, 2016).

Finally, task-based assessment in the classroom has varied advantages for language instruction. First and foremost, as Long (2015) argues, these assessments provide visible evidence of what students can do with language; because of this feature, the data collected from these assessments can help students to improve their language ability and teachers to adjust their teaching. As Norris (2016) states, opportunities abound for students to perform given several stages in TBA implementation, which leads to 
what the author labels as "instruction-related feedback" (p. 238). In addition, Norris states that TBAs have the benefit of engaging students in integrated skills assessment. As shown, language learning benefits from task-based assessments, so Willis (1996) and Willis and Willis (2007) even suggest that students can feel prepared for language examinations provided that they too include tasks for language ability and value authenticity as a condition for language performance.

The next section of this paper synthesizes the information from the previous review and delves into the notion of Instructional Task-Based Language Assessment (ITBA), a proposal to observe TBA in the context of the classroom and how it can be operationalized jointly by teachers and students.

\section{Instructional Task-Based Language Assessment (ITBA)}

In his overview of TBA, Ellis (2003) comments that his discussions are in a vacuum and argues that TBA needs to be conceptualized from where it happens more often: The language classroom. However, discussions of TBA in the language classroom seem scarce (Norris, 2009; 2016; Bygate, 2016) and do not delve into the nature of TBA as it happens in class while teachers and students are engaged in this approach to language assessment.

I therefore believe the literature of TBA has not thoroughly discussed the implementation of tasks for assessment in the classroom. Rea-Dickins (2001) and McNamara and Hill (2011) discuss language assessment as it happens in classrooms, but they do not specifically describe how teachers deal with tasks in the sense that the literature of TBA has conceptualized them. Of course, assessment through tasks was not the goal of these two studies; they shed light on broad assessment stages in language classrooms -planning, presenting, doing, and analyzing assessment data.

What I feel can contribute to further understandings of TBA is a more finegrained and observational stance to what happens as assessment tasks are employed in a classroom. Bygate (2016) recommends that banks of data be built so the field can collect information about classroom practices and useful assessment tasks in instructional TBA. Likewise, Norris (2009, p. 587) explains that language education can benefit "from the actual uses to which assessments are put, the contexts in which they are used, and the individuals or groups who are using them."

As I see it, instructional task-based assessment will necessarily involve assessment in the sense of data collection about language progress over time (Chapelle \& Brindley, 2010) and summative assessment, particularly in the form of grades. However, ITBA must essentially be assessment for learning (Davison \& Leung, 2009), as it seeks to exercise positive impact on teaching and learning. Finally, ITBA is seamlessly 
intertwined with teaching (Rea-Dickins, 2007), as the interrelationships between both processes are evident in classroom scenarios. Finally, ITBA is assessment because of the following characteristics:

- It is, naturally, based on a central task (or tasks) and language activities feed that task, so that constructs are developed and then captured in task performance.

- Judgements about task completion may lead to deciding whether a person can do something through language or what language abilities he/she needs to improve.

- There are robust scoring criteria involved, and these may be used either formatively or summatively, with some emphasis on the former.

- There is feedback in the form of grades and opinions or judgements given to learners by teachers or learners themselves.

- Teachers may use assessment results to improve further learning and teaching; there is a feedback loop between assessment and instruction.

- There are uses of alternative assessment procedures, for example peer or selfassessment.

In conclusion, I propose ITBA as a form of language assessment that is closely related to and empowered by teaching and the learners themselves; as such, ITBA does not necessarily imply a fixed point in time but may rely on a construction of the assessment task and throughout a series of stages (e.g. lessons); finally, ITBA relies heavily on feedback from both teachers and students to improve language learning. Therefore, this approach aligns well with alternative assessment.

\section{A Synthesis of Practices in ITBA}

Based on my review of the literature on TBA, I synthesize what could potentially be good practices for TBA in general. I suggest, however, that the usefulness of such synthesis be evaluated against the particular intricacies of contexts where TBA is used. I present such synthesis in the form of principles in the Table below (left column) and include an example to illustrate how these principles can inform assessment in classroom contexts (right column). 
Table 1. Principles and Related Example for Instructional Task-Based Assessment

\begin{tabular}{|c|c|}
\hline Principles & Instructional Example \\
\hline $\begin{array}{l}\text { A. A task is the center of the TBA. } \\
\text { B. The task is not a one-off; since it } \\
\text { involves performance, students have had } \\
\text { opportunities to do their best in the final } \\
\text { task performance; thus, the TBA is directly } \\
\text { aligned with instruction. } \\
\text { C. There is some sort of connection between } \\
\text { performance in the TBA and real-life use } \\
\text { of language. } \\
\text { D. Performance in the task is supported/ } \\
\text { enhanced by formative feedback that } \\
\text { comes from teachers or other students. } \\
\text { E. A task for TBA involves the use of different } \\
\text { language skills, with a particular focus on } \\
\text { one: for example, reading a text before } \\
\text { orally report something. } \\
\text { F. The TBA uses criteria that clearly } \\
\text { delineates what students will do and how } \\
\text { they will do it. Teacher and students know } \\
\text { these criteria. } \\
\text { G. The TBA has the potential to provide } \\
\text { feedback to improve language learning } \\
\text { and instruction. } \\
\text { H. TBAs can come in the form of various } \\
\text { instruments. } \\
\text { I. The TBA can be assessed on two grounds, } \\
\text { depending on the language focus of a } \\
\text { course: The TBA's language constructs or } \\
\text { task achievement. } \\
\text { J. The TBA allows stakeholders to judge how } \\
\text { well the task was achieved and why this } \\
\text { happened thanks to language ability. }\end{array}$ & $\begin{array}{l}\text { Getting a Cup of Coffee } \\
\text { A. Teacher tells students they will learn how } \\
\text { to ask for a cup of coffee in English. } \\
\text { B. Teacher announces task and asks students } \\
\text { how it can be done; teacher shows an } \\
\text { example, students do listening and } \\
\text { grammar-in-context activities (about the } \\
\text { central task). Students rehearse task and } \\
\text { get formative feedback from classmates } \\
\text { and teacher. } \\
\text { C. Teacher remarks how this is something } \\
\text { people do in real life with language. } \\
\text { D. In rehearsals, students get feedback from } \\
\text { one another and from teacher; feedback } \\
\text { focuses on language aspects and/or task } \\
\text { completion: You can ask for a cup of coffee } \\
\text { in English! } \\
\text { E. Students read menus used in cafes, listen } \\
\text { to someone asking for a cup of coffee in } \\
\text { the target language and take notes. } \\
\text { F. Teacher presents task and assessment } \\
\text { criteria to students. They revisit these } \\
\text { when needed. Teacher explains what } \\
\text { aspects of language are needed for the } \\
\text { task (using clear questions to request, e.g. } \\
\text { "Do you have latte?", pronounce key words } \\
\text { correctly, e.g. sugar, spoonful, etc.). } \\
\text { G. Based on students performance during } \\
\text { rehearsals, teacher analyzes what language } \\
\text { aspects they need to improve so they can } \\
\text { do better in the final task performance. } \\
\text { H. Teacher provides students with a simple } \\
\text { checklist to judge peer or self performance: } \\
\text { - Intonates questions correctly. } \\
\text { - Pronounces key words correctly. } \\
\text { - Requests type of coffee. } \\
\text { - Asks for price. } \\
\text { I. Teacher evaluates whether students } \\
\text { learned the language objectives related to } \\
\text { the task (e.g. requesting, asking for prices, } \\
\text { etc.) and completion of the task itself: Do } \\
\text { you feel students can now ask for a cup of } \\
\text { coffee in English? } \\
\text { J. Teacher makes learners aware of what } \\
\text { they can do through English now and how } \\
\text { they used this language for this particular } \\
\text { purpose. }\end{array}$ \\
\hline
\end{tabular}




\section{Limitations}

Bygate (2016) and Norris (2016) have suggested that initiatives on TBA in classroom contexts be promoted. Thus, there may be (or have been) ongoing studies that report TBA in these scenarios and that I did not report in this manuscript. This may be considered a first limitation. Also, the ideas in this paper represent my analysis of the existing literature. Other authors may provide different interpretations of what TBA can represent for the language classroom. Lastly, given space constraints and the limited information they provide on TBA, I could not include other studies or examples of this approach in classroom contexts, which may have communicated with a wider audience. Regardless of these limitations, I invite teachers and teacher educators to look at the benefits and challenges for ITBA and derive their own contextual implementation.

\section{Conclusions}

In this paper I offered reflections on some issues related to task-based language assessment (TBA). In doing so, I have highlighted that discussions around this topic have centered upon testing-conceived as collection of language performance at a fixed point in time-rather than assessment, or the collection and judgements of language performance data over time in classroom contexts. As scholars agree, the field can benefit from looking at ways in which TBA is operationalized in the classroom, arguably where TBA happens most. Consequently, I have proposed the notion of ITBA to analyze TBA in instructional scenarios.

Task-Based Assessment can be used in classroom contexts because it is amenable to good practice for language teaching in general: Clear objectives, authentic language use, formative feedback, and student-centeredness through alternative assessment (e.g. peer feedback), to name a few. Against these general core tenets, I offered a list with detailed principles to operationalize ITBA. I also provided some limitations for such proposal and the paper overall.

Today, language classrooms are expected to advance people's communicative competence. That seems to be the general consensus in applied linguistics. One way to do this is to implement task-based language teaching, and as I highlight in this paper, instructional task-based assessment. While challenges exist, the use if TBA may help teachers and learners develop communicative ability for real-life purposes. 


\section{References}

Bachman, L. \& Palmer, A. (1996). Language testing in practice: Designing and developing useful language tests. Oxford University Press.

Bachman, L. (2002). Some reflections on task-based language performance assessment. Language Testing, 19(4), 453-76.

Brindley, G. (1994). Task-centred assessment in language learning: The promise and the challenge. In N. Bird, et al. (Eds.), Language and learning: Papers presented at the Annual International Language in Education Conference (Hong Kong, 1993) (pp. 73-94). Hong Kong Education Department.

Brindley, G. (2013). Task-based assessment. In. C. Chapelle (Ed.), The Encyclopedia of Applied Linguistics, pp. 1-6. John Wiley \& Sons.

Brown, J. D. (2004). Performance assessment: Existing literature and directions for research. Second Language Studies, 22(2), 91-139.

Bygate, M. (2016). Sources, developments and directions of task-based language teaching. The Language Learning Journal, 44(4), 381-400. https://doi.org/10.1080 $\underline{\text { /09571736.2015.1039566 }}$

Byrnes, H. (2002). The role of task and task-based assessment in a content-oriented collegiate foreign language curriculum. Language Testing, 19(4), 419-437. https:// doi.org/10.1191/0265532202lt2380a

Chalhoub-Deville, M. (2001). Task-based assessment: Characteristics and validity evidence. In M. Bygate, P. Skehan, \& M. Swain (Eds.), Researching pedagogic tasks: Second language learning, teaching, and testing, (pp. 210-228). Longman.

Chapelle, C., Enright, M. K., \& Jamieson, J. M. (2007). Building a validity framework for the test of English as a foreign language. Routledge.

Chapelle, C. \& Brindley, G. (2010). Assessment. In N. Schmitt (Ed.), An introduction to applied linguistics: Second edition. pp. 247-267. Hodder Education.

Council of Europe (2001). Common European framework of reference for languages: Learning, teaching, and assessment. Cambridge University Press.

Chuanren, K. (2006). A model of formative task-based language assessment for Chinese as a foreign language. Language Assessment Quarterly, (3)2, 207-227. https://doi.org/10.1207/s15434311laq0302_6 
Davison, C. \& Leung, C. (2009). Current issues in English language teacherbased assessment. TESOL Quarterly, (43)3, 393-415. https://doi. org/10.1002/j.1545-7249.2009.tb00242.x

Douglas D. (2001). Language for specific purposes assessment criteria: Where do they come from? Language Testing, 18(2), 171-185. https://doi. org/10.1177/026553220101800204

Ellis, R. (2003). Task-based language learning and teaching. Oxford University Press

Fulcher, G. (2010). Practical language testing. Hodder Education.

Kim, H. (2004). Task-based performance assessment for teachers: Key issues to consider. Teachers College, Columbia University Working Papers in TESOL \& Applied Linguistics, 4(2), 1-5. https://doi.org/10.1787/19939019

Leedham, M. (2005). Exam-oriented tasks: Transcripts, turn-taking and backchannelling. In C. Edwards \& J. Willis (Eds.), Teachers exploring tasks in English language teaching, 93-102. Palgrave MacMillan.

Long, M. (2015). Second language acquisition and task-based language teaching. WileyBlackwell.

McNamara, T. (1994). Measuring language performance. Addison Wesley Longman.

McNamara, T. \& Hill, K. (2011). Developing a comprehensive, empirically based research framework for classroom-based assessment. Language Testing, 29(3), 395-420.https://doi.org/10.1177/0265532211428317

Mislevy, R. J., Steinberg, L. S., \& Almond, R. G. (2002). Design and analysis in task-based language assessment. Language Testing, 19, 477-496. https://doi. org/10.1191/0265532202lt241oa

Norris, J. (2009). Task-based teaching and testing. Edited by M. H. Long \& C. J. Doughty (Eds.), The Handbook of Language Teaching, 578-594. Wiley-Blackwell.

Norris, J. (2016). Current uses for task-based language assessment. Annual Review of Applied Linguistics, 36, 230-244. https://doi.org/10.1017/S0267190516000027

Nunan, D. (2004). Task-Based language teaching. Cambridge University Press.

Pica, T., Kanagy, R., \& Falodun, J. (1993). Choosing and using communication tasks for second language instruction. In G. Crookes and S. Gass (Eds.), Tasks and language learning (pp. 9-34). Multilingual Matters. 
Rea-Dickins, P. (2001). Mirror, mirror on the wall: identifying processes of classroom assessment. Language Testing, 18(4), 429-462. https://doi. org/10.1177/026553220101800407

Rea-Dickins, P. (2007). Classroom-based assessment: Possibilities and pitfalls. In J. Cummins \& C. Davison (Eds.), The international handbook of English language teaching, Vol. 1, pp. 505-520. Springer.

Richards, J.C. \& Rodgers, T. (2001). Approaches and methods in language teaching. Cambridge University Press.

Skehan, P. (1984). Issues in the testing of English for specific purposes. Language Testing, 1(2). 202-220. https://doi.org/10.1177/026553228400100205

Van den Branden, K. (2006). Task-based language education. Cambridge University Press.

Weaver, C. (2012). Incorporating a formative assessment cycle into task-based language teaching in a university setting in Japan. In A. Shehadeh \& C. Coombe (Eds.), Taskbased language teaching in foreign language contexts: Research and implementation, 287-309. John Benjamins.

Wigglesworth, G. \& Frost, K. (2017). Task and performance-based assessment. In E. Shohamy, S. May, \& I. Or. (Eds.), Language testing and assessment: Third edition. Encyclopedia of Language and Education (pp. 121-130). Springer.

Willis, J. (1996). A framework for task-based learning. Addison Wesley Longman Limited.

Willis, D. \& Willis, J. (2007). Doing task-based teaching: Oxford handbooks for language teachers. Oxford University Press.

Origin of article: This article comes from a personal review and analysis of the existing literature on Task-Based Language Assessment. 


\section{Author}

${ }^{*}$ Frank Giraldo holds a BA in English Language teaching from Universidad Tecnológica de Pereira, Colombia; an MA in English Didactics from Universidad de Caldas, Colombia; and an MA in Teaching English as a Second Language from University of Illinois at Urbana-Champaign, the USA. He works as a language teacher educator in the foreign languages department of Universidad de Caldas, Colombia, where he works for the BA in Modern Languages and MA in English Didactics.

ORCID: https://orcid.org/0000-0001-5221-8245

How to reference this article: Giraldo, F. (2020). Task-Based Language Assessment: Implications for the Language Classroom. GIST - Education and Learning Research Journal, 21, 209-224. https://doi.org/10.26817/16925777.828 